\title{
Use of Infochemicals in Pest Management with Special Reference to the Banana Weevil, Cosmopolites sordidus (Germar) (Coleoptera: Curculionidae)
}

\author{
William Tinzaara ${ }^{1,2}$, Marcel Dicke ${ }^{2}$, Arnold van Huis² and Clifford S. Gold ${ }^{1}$ \\ ${ }^{1}$ International Institute of Tropical Agriculture, East and Southern Africa Regional Centre, \\ P. O. Box 7878, Kampala, Uganda; '2aboratory of Entomology, Wageningen University, \\ P. O. Box 8031, $6700 \mathrm{EH}$ Wageningen, The Netherlands
}

(Accepted 9September 2002)

\begin{abstract}
Infochemicals play an important role in the biology of many insect species. An understanding of their role in plant-herbivore-carnivore interactions can be used in the development of tools for the enhancement of environmentally benign alternatives to synthetic pesticides. This review discusses how chemical information mediates ecological interactions between organisms and the role of infochemicals in integrated pest management. Infochemicals can be used in pest monitoring and in pest control, through mating disruption, mass trapping and to aggregate herbivores at delivery sites for biological control agents. Particular emphasis is placed on the potential of using pheromones and kairomones in the management of the banana weevil, Cosmopolites sordidus (Germar) (Coleoptera: Curculionidae), a pest in plantations of East African highland banana and plantain in most banana-growing regions of the world. Cosmopolites sordidus produces an aggregation pheromone that attracts both males and females. This pheromone has been identified and synthesised and is being recommended as an effective agent in the trapping and control of the weevil. The synergism between banana plant extracts (kairomones) and the synthetic pheromone in attracting C. sordidus should be better exploited. Future research areas that can provide information for the development of an infochemical-based trapping system for the management of $C$. sordidus are discussed.
\end{abstract}

Key Words: infochemicals, kairomones, aggregation pheromone, Coleoptera, banana weevil, Cosmopolites sordidus, biological control, pathogenic fungi, predators, synergism

Résumé-Les sémiochimiques jouent un rôle important dans la biologie de beaucoup d'espèces d'insectes. La compréhension de leurs rôles dans les interactions plante-herbivore-carnivore peutêtre utilisée pour le développement d'outils destinés à améliorer les techniques de luttes alternatives aux pesticides de synthèse. Cet article montre comment l'information chimique agit sur les interactions écologiques entre organismes et, discute du rôle des infochimiques dans la gestion intégrée des ravageurs. Les sémiochimiques peuvent être utilisés pour surveiller et contrôler les ravageurs, à l'aide de la technique de la confusion sexuelle et du piégeage de masse et pour rassembler les ravageurs en un lieu donné pour les agents de lutte biologique. Une attention particulière a été portée au rôle potentiel de l'utilisation des phéromones et des kairomones dans la gestion du charançon du bananier Cosmopolites sordidus (Germar) (Coleoptera: Curculionidae), un ravageur 
des plantations de bananiers des hautes terres d'Afrique de l'Est et de la plupart des zones productrices de bananes dans le monde. Cosmopolites sordidus émet une phéromone d'agrégation qui attire aussi bien les mâles que les femelles. Cette phéromone a été identifiée et synthétisée et son utilisation recommandée pour piéger et contrôler efficacement le charançon. Le synergisme entre les extraits de bananier (kairomone) et la phéromone de synthèse dans l'attraction de $C$. sordidus devrait être mieux exploité. Les futurs domaines de recherches pouvant fournir des informations pour le développement d'un système de piégeage à base d'infochimiques pour la gestion de $C$. sordidus sont discutés.

Mots Clés: sémiochimiques, kairomones, phéromone d'agrégation, Coleoptera, charançon du bananier, Cosmopolites sordidus, lutte biologique, champignon pathogène, prédateurs, synergisme

\section{INTRODUCTION}

$\mathrm{A}$ 11 organisms utilise information they perceive from their environment to maximise fitness, e.g. by improving food location, reproduction and predator avoidance. Information on environmental conditions is often available through chemical cues (Bell and Carde, 1984; Carde and Bell, 1995; Dicke, 1999a). Chemicals involved in conveying information in intra- and inter-specific interactions between organisms are termed 'infochemicals' (Table 1) and constitute a subcategory of semiochemicals (Dicke and Sabelis, 1988).

Chemical information is regarded as a key factor mediating behavioural and ecological interactions between insects and plants. The study of chemicals mediating interactions between organisms, either within the same species (pheromones) or from different species (allelochemicals), forms the research field of chemical ecology (Metcalf and Metcalf, 1992; Roitberg and Isman, 1992). In recent years, increased research attention has been directed towards the role of chemical information in arthropod biology (Whittaker and Feeny, 1971; Bell and Carde, 1984; Metcalf and Metcalf, 1992; Roitberg and Isman, 1992; Carde and Bell, 1995; Dicke, 1999a; Dicke and Vet, 1999).

In this review, chemically mediated interactions between organisms and the role of infochemicals in pest management are discussed. Our objectives are to summarise how infochemicals have been used in pest control, indirectly through monitoring and directly through mating disruption, mass trapping and by integration with biological control methods. Limited information is available on infochemicals and the banana weevil Cosmopolites sordidus (Germar) (Coleoptera: Curculionidae). We therefore review the existing literature on coleopterans so as to gain an insight into the possible role of infochemicals in the development of an integrated pest management programme for C. sordidus and in particular the development of an infochemical-based trapping system for the control of this weevil.

\section{Chemical Information IN ECOLOGICAL INTERACTIONS}

Chemicals produced by plants and insects play a major role in the behavioural responses that determine the performance, survival and development of the insects (Vet and Dicke, 1992). The chemicals involved in transmission of information between individuals of the same species are termed pheromones (Table 1). These include sex pheromones, aggregation pheromones and trail pheromones (David and Birch, 1986; Ridgway et al., 1990; Agelopoulos et al., 1999; Bartelt, 1999). Sex pheromones are produced by one sex (usually the female) and attract members of the opposite sex for mating. By comparison, aggregation pheromones lead to aggregation of members of both sexes resulting in mating and aggregation at a food source (Foster and Harris, 1997). These are often produced by males. Maleproduced aggregation pheromones have been demonstrated for a number of weevil species such as Rhynchophorus palmarum (L) (Rochat et al., 1991), R. cruentatus (Weissling et al., 1993), $R$. phoenicis (Fabricus) (Gries et al., 1993), Metamasius hemipterus (L) (Giblin-Davis et al., 1994a), C. sordidus (Budenberg et al., 1993a), and Sitophilus spp. (Walgenbach et al., 1983). Social insects, such as ants and termites, often produce trail pheromones by which individuals may guide other members of the colony to food sources 
Table 1. Infochemical terminology according to Dicke and Sabelis, 1988

Infochemical: A chemical that, in the natural context, conveys information in an interaction between two individuals, evoking in the receiver a behavioural or physiological response

Pheromone: An infochemical that mediates an interaction between organisms of the same species whereby the benefit is to the origin-related organism $[(+,-)$ pheromone], to the receiver $[(-,+)$ pheromone $]$, or to both $[(+,+)$ pheromone $]$

Allelochemical: An infochemical that mediates an interaction between two individuals that belong to different species.

Allomone: An allelochemical that is pertinent to the biology of an organism (organism 1) and that, when it contacts an individual of another species (organism 2), evokes in the receiver a behavioural or physiological response that is adaptively favourable to organism $1 \mathrm{but}$ not to organism 2 .

Kairomone: An allelochemical that is pertinent to the biology of an organism (organism 1) and that, when contacts an individual of another species (organism 2), evokes in the receiver a behavioural or physiological response that is adaptively favourable to organism 2, but not to organism 1 .

Synomone: An allelochemical that is pertinent to the biology of an organism (organism 1) and that, when contacts an individual of another species (organism 2), evokes in the receiver a behavioural or physiological response that is adaptively favourable to both organism 1 and 2 .

(Blum, 1974; Bell and Carde, 1984). Other pheromones produced by phytophagous insects include anti-aggregation pheromones that ensure adequate spacing when resources are limited (Prokopy, 1981), oviposition-deterring pheromones that females use to mark the hosts on which they have laid eggs (Heard, 1995), and alarm pheromones that serve to warn conspecific insects of impending danger (Bowers et al., 1972). Knowledge of pheromones for carnivorous insects is still rudimentary, with a few pheromones indicated for parasitoids (e.g. egg marking pheromones) and predators (Aldrich, 1999).

Herbivores are known to use plant volatiles (kairomones) to locate a food plant (Visser, 1986). When herbivores feed on a plant, cell damage results and there is release of volatiles from the wound site (Dicke et al., 1990). The amount of volatiles released by herbivores or by herbivoreinfested plants may affect herbivore response to the plant. The response to an information source by the herbivore may depend on physiological state, previous experiences and abiotic conditions (Dicke et al., 1998). Host plant selection by herbivores may be affected by infochemicals from competitors (Schoonhoven, 1990) and natural enemies (Grostal and Dicke, 1999).
Chemical information on herbivore presence and identity may be essential for successful location of herbivores by carnivores. Plants may respond to herbivore attack by producing chemical cues that attract carnivorous predators to themselves (Dicke, $1999 \mathrm{a}, \mathrm{b}$ ). The herbivoredamaged plant may emit relatively large amounts of plant volatiles that are not emitted or only emitted in trace amounts by mechanically damaged plants (Dicke et al., 1990). The amount of plant volatiles released after herbivore attack may be different among species, plant genotypes, and plant parts and can be affected by abiotic and biotic factors such as species, instars and densities of the herbivores (Vet and Dicke, 1992). Corn seedlings release large amounts of volatile terpenoids after damage inflicted by Spodoptera caterpillars, which attract the larval parasitoid Cotesia marginiventris (Turlings et al., 1990). Similarly, the predatory mite Phytoseiulus persimilis is attracted by spider mite-induced volatiles produced by bean or cucumber plants (Dicke et al., 1990). The anthocorid predators (Anthocoris nemorum and Orius spp.) (Heteroptera: Anthocoridae) were attracted to pear trees infested by pear psylla under field conditions (Drukker et al., 1995). Prey searching and location is not the only 
process triggered by herbivore-induced plant volatiles. Some predators such as Metasyrphus corollae (Syrphidae), Chrysopa carnea (Chrysopidae) and Coccinella septempunctata (Coccinellidae) use these chemical cues to select oviposition sites (Lewis, 1977; Shonouda et al., 1998; Steidle and van Loon, 2002).

\section{Infochemicals and Insect Pest CONTROL}

Infochemicals, and pheromones in particular, have been used widely in pest management and have been reported to have the advantage of being nontoxic to humans and arthoropods (David and Birch, 1986; Ridgway et al., 1990; Agelopoulos et al., 1999). Pheromones perform most effectively when employed as part of an integrated control programme, where they can be used either indirectly for monitoring (Wall, 1989), or directly to manipulate pest populations (Griffiths et al., 1991). They offer the prospect of establishing contact with microbial control agents by attracting pests into an environment where these agents might be best preserved. This can apply to fungal pathogens, mobile insect predators and parasitoids (Pickett, 1988). The knowledge on infochemical use by plants, herbivores and carnivores can be utilised in the development of new integrated pest control strategies.

\section{Pheromones}

Successful chemical identification of insect pheromones (Butenandt et al., 1959) led to an interest in pheromone research. Pheromones were considered a new generation of pest control agents and rapid progress was made in the identification and isolation of pheromones from a wide range of insects (Table 2). Sex and aggregation pheromones are common among weevils. However, the state of knowledge of weevil pheromones varies broadly among species. For some, there is only an indication that a pheromone exists but for others, there have been detailed behavioural and physiological studies, chemical isolation, identification, pheromone synthesis, and commercial development (Table 2).

Pheromones and other behaviour modifying chemicals hold a great potential as tools for pest management (Silverstein, 1981; Phillips, 1997; Agelopoulos et al., 1999; Suckling, 2000).
Pheromones have been used in both monitoring insect populations and in direct control (Phillips, 1997; Agelopoulos et al., 1999). Pheromone traps provide an easy and efficient way of detecting insect populations in the field and in storage facilities (Phillips, 1997). Control of insect pests can be achieved either by mating disruption (Burkholder and Ma, 1985) or by mass trapping using pheromone baited traps that lure insects to their death (Giblin-Davis et al., 1994a) (Table 2). Pheromones also have the potential to lure pests into traps containing entomopathogens that the visiting pests would then spread throughout their population (Vega et al., 1995; Klein and Lacey, 1999).

Although there have been limited successes, the potential exists for using pheromones to control coleopteran populations by mass trapping. The advantage is that, with few exceptions, coleopterans use aggregation pheromones, attracting both sexes which negatively affect the reproductive capacity of the population (Trematerra, 1997; Bartelt, 1999). This makes mass trapping using aggregation pheromones theoretically possible, in contrast to the systems with female-produced sex pheromones where more than $90 \%$ of males must be captured to effect any depletion of the following generation (Bartelt, 1999). Mass trapping is most promising for insect pests with low fecundity, slow population buildup, limited dispersal and long life span (Giblin-Davis et al., 1996a). Pheromone traps are species-specific and the negative impact on nontargets is limited. Other benefits of using pheromones in pest management include their low costs and low potential for development of pest resistance.

\section{Monitoring}

Pheromones have been used for monitoring pest populations of crop pests and orchard pests (Wall, 1989), stored products pests (Burkholder, 1990) and forestry pests (Borden, 1993). Monitoring can assist in detecting the arrival of dispersing and migrating insect pests, timing of control measures, risk assessment and population density estimates (McVeigh et al., 1990; Howse et al., 1998). Monitoring involves establishing a quantitative relationship between pheromone trap catches of a particular pest and the plant damage caused by it. The relationship is then used to define trap catch values that could be used to identify the economic 


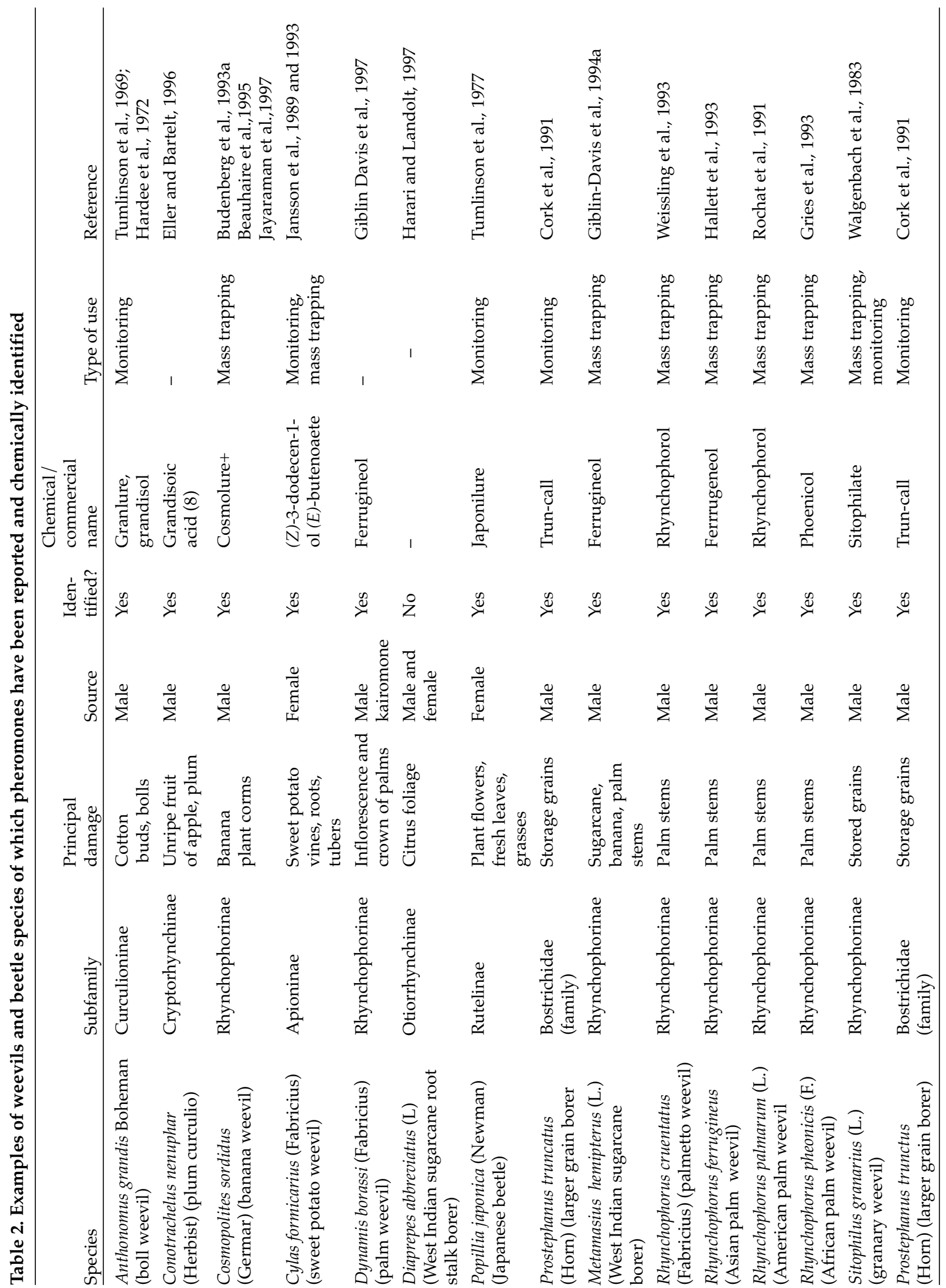


threshold level of a pest for which control measures are necessary (Suckling, 2000). The monitoring systems have enabled more effective targeting of all major pest control tactics including pesticides and biopesticides (Suckling, 2000).

Although commercial advances in pheromonerelated pest monitoring and control technology have tremendous potential (Howse et al., 1998; Smit et al., 1997), there remain challenging technological issues in the development and use of monitoring and control systems (Suckling, 2000). These include the design of attractant release systems, trap design and deployment systems, data analysis and interpretation and the development of expert decision systems. Obtaining quantitative information about pest populations from trap catch data has proved difficult in many cases, especially for strongly flying, highly mobile species which may be able to escape from sticky substances commonly used in insect traps (Srivastava et al., 1992). In some cases pest species have been trapped successfully in the field but their presence did not correlate well with pest density and damage levels (David and Birch, 1986). There have also been examples of insect species not being caught by ineffective traps and causing crop damage (Tadas et al., 1994).

\section{Mating disruption}

Mating disruption involves permeating the pest environment with sex pheromones so that the probability of a female being found by a male, mating and laying viable eggs is reduced below a point where economically significant damage occurs (Carde and Minks, 1995; Evenden et al., 2000). Pest control by use of synthetic pheromones to disrupt normal mating behaviour is now operational for a number of lepidopteran species such as the pink boll worm, Pectinophora gossypiella, the cotton boll worm, Helicoverpa armigera and the rice stem borer, Chilo suppressalis (Campion et al., 1989; Hall et al., 1994; Carde and Minks, 1995; Cork et al., 1996; Tamhankar et al., 2000). Use of pheromones in mating disruption of coleopteran pests has been reported for Cylas formicarius (F) (Mason and Jansson, 1991) and for the African sweet potato weevils, C. brunneus and C. puncticollis (Downham et al., 2001).

One potential weakness of mating disruption is that this technique provides no safeguards against migration of mated females from outside the area treated with a disruptant (Carde and Minks, 1995). Thus, mating disruption can work best as an area-wide management tool (Staten et al., 1997) rather than being used by an individual farmer. A high population density of the target insect can also limit the control efforts especially if there is competition between synthetic and female-produced plumes (Carde and Minks, 1995). Lures involved in mating disruption should be formulated to release at sufficiently high rates to prevent mating (Suckling, 2000). Effective mating disruption requires a high proportion of males failing to mate females and therefore, longlived species that can mate on multiple occasions are more difficult to control (Suckling, 2000).

\section{Mass trapping}

The aim of mass trapping is to control insect species by capturing a very large proportion of the pest population by deploying pheromone traps in sufficient numbers. Such an approach assumes that a reduction in the adult population will lead to a further population decrease in the next generation (Birch and Haynes, 1982). In mass trapping strategies it is important to know the proportion of the population that is captured and the relationship between this proportion and the reduction in the population of the next generation. In lepidopterans, mass trapping using sex pheromones has varying degrees of area-wide and prolonged success (Kehat et al., 1980; Mafra-Neto and Habib, 1996; Tamhankar et al., 2000). This may have two causes: (1) the sex pheromone (produced mostly by females) attracts only males (and then not all of them) and (2) the males are polygamous and a small proportion of untrapped males can continue to fertilise a substantial number of females with high egg laying potential (Tamhankar et al., 2000).

Several studies have tested the potential of the mass trapping strategy for the control of coleopteran insects. This strategy was tested against the spruce bark beetle, Ips typographus (L)(Bakke, 1981), the Japanese beetle, Popillia japonica Newman (Ladd and Klein, 1982), the boll weevil Anthonomus grandis grandis Boheman (Hardee, 1982), the European bark beetle, Scolytus multistriatus (Marsham) and the ambrosia beetle Gnathotrichus sulcatus (LeConte) (Birch and Haynes, 1982). Some authors (Oehlschlager et al., 1995; Alvarez, 1996) have reported successful 
suppression of the pest populations by use of mass trapping. Use of pheromone traps significantly reduced the damage from Cylas infestation on potato plants in the Dominican Republic (Alvarez, 1996). Oehlschlager et al. (1995) described a 17months mass trapping trial in Costa Rica during which the population density of the weevil Rhynchophorus palmarum in a 30 ha commercial palm plantation was substantially reduced using 6 traps/ha. Cost-benefit analyses of using pheromones in mass trapping for successful studies have, however, rarely been carried out.

Mass trapping using pheromones should be considered as one component of a set of pest management practices. Deployment of traps alone may not result in suppression of a pest population, especially when the target insect is abundant and has a high multiplication rate (Birch and Haynes, 1982; Weislein, 1992; James et al., 1996). Cuthbert et al. (1977) indicated that large numbers of naturally attractive sites (e.g. crop residues) competed with traps and hence reduced the trapping effect of scolytid beetles, S. multistriatus. Therefore, to suppress populations of the elm bark beetle, S. multistriatus (Birch and Haynes, 1982) and the spruce bark beetles, Ips typographus (Weislein, 1992), mass trapping should be conducted in conjunction with rigorous sanitation programmes. The same is true for the mass trapping of Carpophilus spp. in stone fruit orchards (James et al., 1996) and R.palmarum in plantations of African oil palm (Oehlschlager et al., 1995).

High trap densities and high trapping frequency are often needed to obtain satisfactory levels of population suppression (Lloyd et al., 1981). Continuous trapping of $A$. grandis at high population levels indicated that as many as $92 \%$ of the males emerging from a population were captured with a trap density of 14 traps / ha (Lloyd et al., 1981). Such high trap densities are not practical as they render the technique too costly. In contrast, with low population levels, a density of 2.5 traps/ha resulted in a high rate of elimination of $A$. grandis (Legget et al., 1989). Mass trapping tends to be more effective at low population densities as was reported for $A$. grandis (Lloyd et al., 1981; Legget et al., 1989; Ridgway et al., 1990).

Two major questions have always been raised regarding trap density (David and Birch, 1986; Howse et al., 1998). First, what trap density is required to adequately sample the pest population? Second, at what density do traps interact thereby influencing the size of the catch in the individual traps? Answers to these questions will help in optimising trap placement that is critical to the success of mass trapping efforts.

\section{Trap effectiveness}

A number of factors influence the rate of captures of insects in pheromone traps. Pheromone dose and release rate influence how traps perform relative to natural pheromone sources and thus determine how well they attract insects (Muirhead-Thompson, 1991; De Groot and De Barr, 1998). Insects may respond to the colour of a trap and certain trap designs capture insects more efficiently (Giblin-Davis et al., 1996b; Smit et al., 1997; De Groot and De Barr, 1998). In field studies using aggregation pheromones as trap baits, all trap colours tested were equally efficient in attracting $M$. hemipterus to ground-mounted bucket traps (Giblin-Davis et al., 1996a) and R. palmarum to tree-mounted traps (Oehlschlager et al., 1993). Anthonomus grandis responded positively to yellow from a distance of approximately $7 \mathrm{~m}$ and at $2 \mathrm{~m}$ the majority of weevils orient to this colour rather than the pheromone (Legget and Cross, 1978). Placement of the traps near, within, or away from the host plants may affect the trap capture depending on the link between the host and mate finding (McNeil, 1991; Muirhead-Thompson, 1991). Catches may also correspond to the timing of placement of the traps in populations with distinct generations (Jansson et al., 1991).

Trap catches in most cases correlate to environmental factors such as wind direction and speed, rainfall and temperature (Jansson et al., 1989; Sappington and Spurgeon, 2000). Wind speed and direction may alter pheromone plume shape and size, and create pheromone concentration gradients within the plume. Upwind orientation by insects to pheromones is well known, but information on the influence of wind is not available for ground-dwelling insects where wind speed is negligible. Little research has been carried out to examine the influence of relative humidity on pheromone-mediated communication in Coleoptera. For Lepidoptera, Miller and McDougall (1973) found a negative relationship between trap catch and relative humidity in a 12-year trapping study on the 
spruce budworm. Responsiveness of pests to pheromones has been demonstrated to increase with temperature (Burkholder and Bousch, 1974; Burkholder and Ma, 1985). Variation in pheromone trap catches with temperature may be attributed to increased response in the receiver and better distribution of the chemicals.

The trap efficiency is further affected by the pest biology. Mated females of $A$. grandis were less responsive to male-produced sex pheromone (grandlure) than virgin females, both in laboratory bioassays and in field tests (Hardee et al., 1969). In insect species in which virgin females are trapped, the reduction in the subsequent generation may be directly related to the proportion removed from the population. If females are trapped after mating and after having laid some eggs, the efficiency of the method decreases. If males were trapped, a very large proportion probably would have to be captured before there is a noticeable impact on the next generation. This is true for many insect species in which both males and females are capable of mating many times (Borden, 1977).

The pheromone trap efficacy is also influenced by interaction of the cropping system and the biology of an insect pest (Hebblethwaite, 1989). For polyphagous pests that have non-crops as host plants, uncultivated areas and weed populations are important elements of the farming system relevant to pest incidence. For pests having only one crop as host, the pattern of cultivation and proportion of land cultivated are some of the factors that determine their importance. The pheromone trapping efficiency is influenced by the cropping patterns (monocropping or mixed cropping), but it is also possible that within a cropping pattern there are still zones where the pest may be more important than elsewhere which may affect the trap catches. To develop an effective pheromone trapping system, biological information, such as the number of generations per year, range of host plants, dispersal rate, distribution pattern and migratory potential of the pest is generally needed (Borden, 1977).

\section{Kairomones}

Many insects use kairomones to find their host plants (Visser, 1986). Among the coleopterans, the boll weevil, A. grandis, orients to volatile chemicals emanating from its host plant cotton (Hardee et al., 1966) and also responds to crushed cotton squares (Dickens, 1989). Colorado potato beetles are attracted to volatiles from undamaged potato plants (Visser, 1986) but volatiles from mechanically damaged or herbivore-damaged potato plants elicit a stronger attraction in the beetles (Bolter et al., 1997). Female and male sugarcane stalk borer weevil, Diaprepes abbreviatus (L) were reported to be attracted to volatiles from damaged food (Harari and Landolt, 1997). Male and females of the plum curculio, Conotrachelus nenuphar (Herbst) are similarly attracted to host odour (Prokopy et al., 1995). Several studies have demonstrated the attractiveness of pseudostem and sugarcane stalk odours to palm weevils in the field (Giblin-Davis et al., 1994b). Mixtures of odorants synergistically attracted the Japanese beetle, Popillia japonica (Tumlinson et al., 1977) and bark beetles (Byers, 1992). There are hardly any data about the maximum distance from which kairomones can attract insects.

The efficiency of the kairomones in attracting insects depends on the odour quality and/or the amount released. Bark beetles prefer to attack and colonise dying trees that have odours that are distinctively different from those of healthy trees (Metcalf and Metcalf, 1992). Fermented plant tissues produce a spectrum of odorants that are significantly different from those released by healthy plants (Metcalf and Metcalf, 1992; GiblinDavis et al., 1994b; Braimah and van Emden, 1999; Rochat et al., 2000). Fermented sap exuding from dead or wounded palms was highly attractive to R. cruentatus (Giblin-Davis et al., 1996a). Moist fermenting tissue from various palm species, fruits, sugarcane, pineapple and molasses are similarly attractive to palm weevils (Giblin-Davis et al., 1994b). In olfactometer bioassays, kairomones triggered the primary attraction of African palm weevils, R. palmarum, to oil palm. Fermentation processes were important to elicit this behaviour (Rochat et al., 2000).

In addition to being used as attractants of insects to traps, kairomones can be used to enhance attractiveness of insects to pheromonebaited traps (Phillips et al., 1984; Giblin-Davis et al., 1994b; Cerda et al., 1999). They may also be used in the dissemination of entomopathogens to target insects (Vega et al., 2000). Plant-produced kairomones that mediate host selection by phytophagous insects could also be exploited to enhance breeding for host plant resistance. 
Synergism between pheromones and kairomones

Host plant volatiles (kairomones) are known to enhance the effectiveness of pheromone traps in attracting weevils (Dickens, 1984; Phillips et al., 1984; Giblin-Davis et al., 1994b; Cerda et al., 1999). In the pine weevil Pissodes nemorensis, the maleproduced aggregation pheromones grandisol and grandisal were attractive in the field only when deployed with odours from the host plant (Phillips et al., 1984). The maize weevil, Sitophilus zeamais, responded significantly more to male-produced pheromones deployed with grain than to either pheromone or grain separately (Walgenbach et al., 1987). Ambrosia beetles in the genus Gnathotrichus utilise male produced pheromones that act synergistically with the host-derived compounds $\alpha$-pinene and ethanol (Borden et al., 1980). Green leaf volatiles have a synergistic effect on the attraction of the boll weevil to its pheromone (Dickens, 1984). The combination of R. palmarum weevils and palm stem was attractive to both sexes of this species, and males without host material were not attractive to either sex in field trials (Rochat et al., 1991). Attraction of palm weevils by the synthetic pheromone rhynchophorol is synergised by the addition of host material, such as palm stem or sugarcane (Oehlschlager et al., 1993), or by host odour compounds, such as ethyl acetate (Jaffe et al., 1993). Attraction of male and female R. cruentatus to male pheromone 5-methyl4-octanol (cruentol) is synergised by volatiles from host plant material, such as Sabal palm stem tissue (Giblin-Davis et al., 1994b). The response in the field of the West Indian sugarcane borer, $M$. hemipterus, to the aggregation pheromone was enhanced by fermented and fresh plant volatiles (Giblin-Davis et al., 1994a). Increasing quantities of sugarcane or host tissue generally increase attractiveness of pheromone-baited traps to $M$. hemipterus (Oehlschlager et al., 1993; Giblin-Davis et al., 1994b).

\section{INFOCHEMICALS AND BIOLOGICAL CONTROL}

\section{Predators and parasitoids}

There has been increasing interest in the implementation of biological control programmes using parasitoids and predators and the efficacy of these natural enemies may be enhanced by infochemicals (Vet and Dicke, 1992; Dicke, 1999a). Application of infochemicals in pest control is, however, impossible without knowledge of the behaviour induced by these chemicals (Gross, 1981). Infochemical use, both within and between species can be utilised in pest management by either exploiting the way the natural enemy responds or by manipulating the source of the infochemical (Dicke et al., 1990; Bottrell et al., 1998). For example, infochemicals can be used to enhance the searching efficiency, host utilisation and reproductive capacity of natural enemies (Lewis and Nordlund, 1985; Noldus, 1989; Renwick, 1992; Bottrell et al., 1998).

There are few cases of the application of infochemicals to manipulate the behaviour of predators in the field. However, data on the role of infochemicals in predator foraging have become available for some groups such as predatory mites (Sabelis and Dicke, 1985; Dicke and Sabelis, 1988), bark beetle predators (Aukema et al., 2000), heteropteran predators (Van Loon et al., 2000) and coccinellids (Liu and Sengonca, 1994; Steidle and van Loon, 2002). The predator Rhizophagus grandis (Gyll.) (Coleoptera: Rhizophagidae) is attracted to traps baited with a kairomone produced by the bark beetle Dendroctonus micans Kug (Coleoptera: Scotylidae) (Aukema et al., 2000) and in this way the predator distribution in the field can be monitored. The search time of predators may be reduced through increased aggregation at infested sites or kairomone sources (Vet and Dicke, 1992).

The performance of natural enemies can be enhanced by changing their environment by using infochemicals. Predators and parasitoids may be retained in the target area or their search and attack behaviour may be improved (Noldus, 1989; Lewis and Martin, 1990). Hagen et al. (1971) used artificial honeydew as stimulus to increase predation of Heliothis zea by Chrysoperla carnea (Stephens). The chemical provided both a kairomone and food supplement that increased predator density around cotton plants. Detailed behavioural studies in patches of cotton plants containing host larvae revealed that when nectar was present in the patch, the wasp Microplitis croceipes (Cresson), a parasitoid of $H$. zea larvae stayed longer and parasitised more hosts than when nectar was absent (Stapel et al., 1997). Similarly the release of a synthetic blend of the sex pheromone of $H$. zea in cotton increased parasitism of eggs from $21 \%$ in control to $36 \%$ in treated plots (Lewis et al., 1982). 
A thorough behavioural analysis is needed for drawing conclusions on the role of infochemicals in predator and parasitoid foraging strategies and thus to employ such chemicals in pest control (Noldus, 1989; Dicke et al., 1990; Renwick, 1992; Dicke, 1999a). We need to: (i) know desirable traits of natural enemies and the mechanism(s) by which infochemicals influence these traits, (ii) have the technological ability to manipulate these traits prior to and / or after release, and (iii) know the potential negative effects such as the attraction of pest insects (Bolter et al., 1997).

\section{Fungal pathogen dissemination}

Although certain fungal pathogens have been recognised as potential biological control agents of insect pests (Kaya et al., 1993; Nankinga, 1994), their commercial use has been limited by technical problems to do with their delivery to the target pests (Kaya et al., 1993; Lacey et al., 1994; Nankinga et al., 1996; Nankinga and Ogenga-Latigo, 1996). Practical delivery of biocontrol agents to the damaged area of the plant remains a challenge because conventional application techniques are typically not cost effective and the target organisms are often difficult to reach. One possible mechanism of targeted delivery is by contaminating insects with pathogens and letting them spread the infective material (McLaughlin et al., 1969; Shapas et al., 1977; Pell et al., 1993; Lacey et al., 1994). Pheromone traps have been identified as possible lures for inoculation devices and subsequent pathogen dissemination (Vega et al., 1995; Klein and Lacey, 1999; Vega et al., 2000). The movement of infested hosts is considered to be one of most important ways in which a pathogen can be transmitted and dispersed to new habitats (Shapas et al., 1977; Vega et al., 2000). With an effective pheromone and luring device, it may be relatively easy to expose the attracted insects to a pathogen. These insects would then leave the trap on habituation to the pheromone and return to the crop disseminating the entomopathogen among their own population (autodissemination). The hoped for advantage of such inoculation rather than immediate killing with the insecticide would be the potential for the transmission of the pathogen to other insects in the immediate area, magnifying the effect of the treatment. It would be relatively easy in this inoculation technique to contaminate insect stages hidden inside the plant tissues with pathogens especially when the egg laying female is infested (Zimmermann et al., 1992). This technique allows for specific and targeted delivery of the bioactive agent that would not be possible using conventional methods (Vega et al., 2000). The effectiveness of the auto-dissemination delivery system of fungal pathogens may however be influenced by the biology (the population dynamics and rate of dispersal) of the target insects.

Various reports are available where pheromones have been used effectively in the dissemination of fungal pathogens (McLaughlin, 1969; Schwalbe et al., 1974; Shapas et al., 1977; Vega et al., 1995; Klein and Lacey, 1999). A bait containing a feeding stimulant and the protozoan, Mattesia grandis was effectively used in spreading the pathogen throughout cotton fields for the control of $A$. grandis (McLaughlin, 1969). In laboratory tests, $96 \%$ of the test insects placed in the inoculation devices treated with pheromone and pathogen got contaminated compared to $56 \%$ that picked pathogens from inoculation devices containing only Mattesia pathogens (Schwalbe et al., 1974). In the field, over $95 \%$ of the Japanese beetle (Popillia japonica) that passed through the auto-dissemination traps during a one-week period died within the 10-day observation period while the control mortality during the same period was 8\% (Klein and Lacey, 1999). The inoculative device becomes practical especially when the trap is baited with a pheromone lure that aggregates insects of both sexes (Vega et al., 1995).

\section{INFOCHEMICALS AND BANANA WEEVIL CONTROL}

Cosmopolites sordidus is considered to be one of the most serious pests of bananas (Stover and Simmonds, 1987). The insect can cause yield loss of up to $100 \%$ (Sengooba, 1986; Koppenhoeffer et al., 1994) through sucker death, toppling and snapping (Sikora et al., 1989; Rukazambuga et al., 1998; McIntyre et al., 2002), and shortens plantation life spans if not controlled (Rukazambuga et al., 1998; Gold et al., unpubl. data). For information on biology and population dynamics of the banana weevil, see extensive reviews by Gold (1998) and Gold et al. (1999b).

Control of this pest has depended on the use of synthetic insecticides, which, though feasible 
for larger commercial growers, is beyond the economic capacity of most banana producers in developing countries such as Uganda. Furthermore, C. sordidus is resistant to a wide range of chemicals (Collins et al., 1991; Gold et al., 1999a). There are hardly any bananas and plantain varieties identified with useful tolerance or resistance to C. sordidus (Ortiz et al., 1995). The control of the weevil by cultural methods such as mulching or the use of split pseudostem traps to catch and kill resident and invading weevil populations has been only partially successful (Okech et al., 1999; Gold et al., 2001). Trapping as a control method is influenced by environmental factors, weevil biology, trapping intensity and frequency (Bakyalire, 1992; Gold, 1998). Efficacy of trapping is also related to trap density, trap placement, quality of traps, size of traps and frequency of collection (Bakyalire, 1992; OgengaLatigo and Bakyalire, 1993; Koppenhoeffer et al., 1994). Re-invasion from neighbours' fields may be another problem (Okech et al., 1999; Gold et al., 2001). Enhanced trapping using infochemicals, including pheromones and kairomones, has been identified as a means that can be used to develop an effective method of trapping and controlling the weevil. Below we discuss the role of pheromones and kairomones, and their integration with biological control methods for the management of $C$. sordidus.

\section{Pheromones}

Evidence for a male-produced aggregation pheromone to which both females and males of C. sordidus respond was first provided by Budenberg et al. (1993a). Beauhaire et al. (1995) detected six male-specific compounds with electroantennogram (EAG) activity in volatile collections. They identified and synthesised sordidin (2,8-dioxa-1-ethyl-3,5,7-trimethylbicyclo[3.2.1] octane) (Fig. 1), which was the most abundant of the volatiles. The absolute stereochemistry of the natural sordidin was later determined (Mori et al., 1996; Fletcher et al., 1997). Ndiege et al. (1996) and Jayamaran et al. (1997) developed a large-scale synthesis of racemic sordidin that made field-testing possible. It was attractive to both males and females, confirming its function as an aggregation pheromone. This has been synthesised to provide cosmolure pheromones that together with traps are

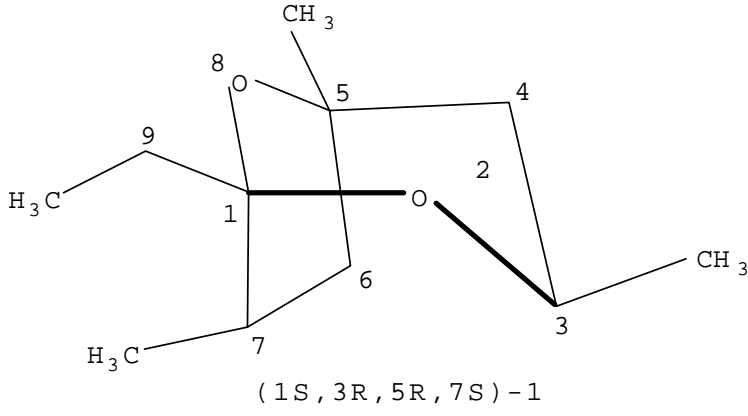

Fig. 1. Configuration of sordidin, a major component of the pheromone cosmolure+

commercially available from ChemTica International in Costa Rica.

The use of pheromone lures (cosmolure+) for trapping C. sordidus has been reported in Costa Rica as a promising option (Alpizar et al., 1999; Oehlschlager et al., 2000). Trials of mass trapping in plantations of banana and plantains with pheromone traps on plots of 1-250 ha in size, and traps at a density of four per ha were effective in reducing weevil damage to banana corms by over $60 \%$ and bunch weight was increased by $20 \%$ (Alpizar et al., 1999; Oehlschlager et al., 2000). Alpizar et al. (1999) proposed that trap density could be reduced once weevil populations and damage have been reduced to low levels. In Costa Rica, trap interference starts to decrease at a separation of $20 \mathrm{~m}$ (C. Oehlschlager, pers. commun.), and the effective radius was estimated to vary from 5 to $15 \mathrm{~m}$. Consequently, a trap density of four traps/ha and moving them every month at regular space intervals was found effective to bring $C$. sordidus populations to low levels in the banana plantation in 4-5 months (Alpizar et al., 1999; Oehlschlager et al., 2000). Preliminary studies conducted in Uganda showed pheromones to be 18 times more attractive to $C$. sordidus than pseudostem traps (Tinzaara et al., 2000).

In laboratory and field studies, male-produced aggregation pheromones for some coleopteran insects are ineffective unless combined with host plant volatiles (Oehlschlager et al., 1992; GiblinDavis et al., 1996a). The weevil appears to show a similar trend of synergistic combinations of speciesspecific pheromone and host plant volatiles (Ndiege et al., 1996; Jayaraman et al., 1997).

Mass trapping using infochemicals, especially pheromones, is particularly promising for the 
control of $C$. sordidus since the weevils crawl and do not disperse, both sexes are attracted, and their reproductive capacity is low (Alpizar et al., 1999). Use of pheromones may provide a weevil control option that is less labour intensive compared to the use of pseudostem traps although costs are likely to increase as pheromones will require importation, distribution and storage. The development of the infochemical-based trapping system could also be used as a means of disseminating entomopathogens with baited traps which allow both entry and exit of weevils. Further research is necessary to develop these ideas.

\section{Kairomones}

Cuille (1950) first suggested that plant kairomones attract the banana weevil to the host plants. Volatiles from the susceptible AAA cooking banana attracted more weevils than the $A B$ resistant dessert types (Budenberg et al., 1993b). Seshu Reddy et al. (1993) showed that baits of cooking bananas are more attractive to the weevil than those made of dessert bananas. Decaying banana material is more attractive than fresh material (Budenberg et al., 1993b) although it is reported that fresh pseudostems are more attractive than fermented material (Hord and Flippin, 1956; Delattre, 1980). Cosmopolites sordidus seems to prefer corm odours from plants with fruits to corm odours from young or adult plants, or from adult plants with flowers (Cerda et al., 1996). Preliminary studies conducted at ICIPE in Kenya indicate that use of kairomone-based trapping systems with processed and buried banana materials attract weevils (S. Lux, pers. commun.). This trapping system might be integrated with entomopathogens.

The potential of using banana kairomones, especially fermented tissues, as synergists to synthetic pheromones has not been well exploited, although there is information indicating that banana plant volatiles could be used to enhance the attractiveness of synthetic pheromones (Ndiege, 1996; Jayaraman et al., 1997). Further research is needed on host plant odours to optimise the use of kairomones in an infochemicalbased trapping system for $C$. sordidus control.

\section{Infochemicals and biological control of $C$. sordidus}

Studies regarding the effect of infochemicals on the behaviour of predators of $C$. sordidus are currently not available. However, ant and non-ant predators for $C$. sordidus have been reported from Kenya (Koppenhoeffer et al., 1992), Uganda (Tinzaara et al., 1999, A. Abera, pers. commun.), and Cuba (Roche and Abreu, 1983; Bendicho, 1987). These predators were mostly found associated with weevil environments in rotten pseudostem tissues and in larval tunnels (Koppenhoeffer et al., 1992; Tinzaara et al., 1999). Attraction of predators by the volatiles from the plant-weevil complex has not been investigated yet. It is possibe that these predators are attracted to the weevil environments by volatiles produced by the host plant, the weevil or the weevil-plant complex. Although synthetic pheromones (cosmolure+) are known to be specific to C. sordidus, their effect on the behaviour of predators has not been investigated. Information on how infochemicals influence the behaviour of the predators may increase their chance of being used in the field as biological control agents.

The potential of biological control of C. sordidus using indigenous entomopathogenic fungi has been recently investigated (Pena et al., 1995; Nankinga and Ogenga-Latigo, 1996; Nankinga et al., 1996; Nankinga, 1999; Schoeman and Schoeman, 1999; Nankinga and Moore, 2000). Beauveria bassiana showed a great potential for effective control of C. sordidus (Pena et al., 1995; Nankinga et al., 1996). One of the limiting factors is the lack of an effective delivery technique to the target insects (Nankinga, 1999). The potential of infected weevils being used in transferring pathogens to their uninfected counterparts was demonstrated by Schoeman and Schoeman (1999). Dissemination of $B$. bassiana using pseudostem traps was tested but found ineffective (Nankinga, 1999). The development of a pheromone lure could be used as a means for aggregating weevils to disseminate the entomopathogens. The use of pheromone lures as successful devices for dissemination of $B$. bassiana has been reported for other beetle species (Vega et al., 1995; Klein and Lacey, 1999). An above-ground ramp trap that allows both entry and exit of weevils (Alpizar et al., 1999; Oehlschlager et al., 2000; Tinzaara et al., 2000) could be used in this regard. 


\section{Future Research Needs}

Studies available indicate that there is a potential for using infochemicals to control C. sordidus (Alpizar et al., 1999; Oehlschlager et al., 2000; Tinzaara et al., 2000). Further information is needed to develop a cost-effective infochemicalbased trapping method to control C. sordidus. Information is lacking on how infochemicals relate to weevil behaviour and environmental conditions. Other questions to be addressed are: does adult removal using infochemicals have an impact on weevil population dynamics and damage; and can infochemicals be integrated with other methods such as biological control?

The efficiency of the pheromone traps may be influenced, among other factors, by the physiological status of the pest, such as its reproductive maturation and mating status (Borden 1977; Jansson et al., 1991). Although pheromone lures are known to attract female and male weevils equally (Alpizar et al., 1999; Tinzaara et al., 2000), there is lack of information on the effect of the pest mating status and the age of $C$. sordidus on catches in pheromone-baited traps. We hypothesise that if mature and mated individuals do not respond to the pheromone lures, then trapping will cause limited suppression of the weevil population in the field.

Catches per trap are reduced when baited traps with synthetic pheromones are placed close to each other (trap interference) compared to widely spaced single traps (Schlyter, 1992; Byers, 1999). The effective trap radius has direct implications on the trap density used and the costs involved and therefore there is a need to get a more accurate value of the radius before pheromone traps can be used in mass trapping. Trap placement influences the capture rates for many insect pests (McNeil, 1991; Muirhead-Thompson, 1991). It is not clear whether the banana host plant has any influence on pheromone trap catches although we hypothesise that traps placed close to mats capture more weevils than traps placed between mats. Information is therefore required on the attraction range of the pheromone trap, its effective radius and on trap location relative to the host plant.

High trap densities may be needed to obtain high levels of pest population suppression (Howse et al., 1998), but they may not be practical especially to resource-poor farmers, as they render the method too costly. The trap density of four traps per hectare and moving the traps to new locations once a month was reported effective in reducing weevil populations to low levels within 4-5 months in Costa Rica (Alpizar et al., 1999). The assumptions here are: (1) the weevil movements are limited and there is no reinvasion of areas that have already been cleared; and (2) the traps remove a high proportion of weevils within the trap area in a month. The percentage population reduction using pheromone traps was however estimated using trap catch numbers and not overall population densities in the banana plantations. The effectiveness of a trap density of four traps per hectare needs to be evaluated under different agroecological conditions. Placing traps in the whole plantation without changing trap location monthly could be cost effective if the time taken to reduce weevil populations is low. Information is needed on the proportion of weevils trapped per unit area so as to make decisions on when to change the location of the traps (in case of mobile traps) and when to stop trapping when the population has been reduced to low levels. The rate of reduction of weevil population and damage using different trap densities needs to be determined. The question that should be answered here is which trap density is most cost effective. The pheromone trap catches need to be correlated to environmental factors such as wind direction, rainfall and temperature. Such information would assist farmers in managing their traps.

Deployment of pheromone traps alone may not result in pest population suppression when host material is abundant, providing good conditions for pest multiplication (Birch and Haynes, 1982; Vite and Baader, 1990; James et al., 1996). Many crop residues compete with traps, thereby reducing the effect of the traps. The effect of banana residue management on pheromone trap catches is not known. Mulching influences weevil movements in banana plantations (C. Gold and G. Kagezi, unpubl. data), but how much this would affect pheromone trap catches is not known. Therefore, the influence of farm management practices such as mulching and sanitation on pheromone trap catches needs to be studied.

Herbivore-damaged plants are known to produce volatiles that attract carnivores (Dicke, 1999a). Such volatiles may lead to increased carnivore density around the plant that may lead 
to reduced herbivore damage. Predators of $C$. sordidus are normally found in weevil-infested rotten pseudostems and galleries (Koppenhoeffer et al., 1992; Tinzaara et al., 1999; A. Abera, pers. commun.). Are these predators attracted to such environments by volatiles produced by the host plant, weevil or the weevil-plant complex? The role of pheromones in influencing such an interaction has not been investigated.

The potential of using B. bassiana in Uganda to control C. sordidus was promising (Nankinga, 1999; Nankinga and Moore, 2000). However, one of the limiting factors is the lack of an effective delivery technique (Nankinga, 1999; Roy and Pell, 2000). Use of pheromone lures to infest beetles with B. bassiana and to disseminate it to other beetles is possible (Klein and Lacey, 1999; Vega et al., 2000), but needs to be studied for $C$. sordidus.

In conclusion, there is limited information on the use of infochemicals for the control of $C$. sordidus. However, according to the available information on other coleopteran insects, there is a potential for development of an infochemicalbased trapping system for the control of $C$. sordidus. There are however research areas that need to be investigated to generate information for use in developing an infochemical-based trapping system for the control of $C$. sordidus. Research aimed at investigating some of the aspects mentioned in this review has been initiated in Uganda.

Acknowledgement-Financial support from Wageningen University Fellowship Program and a Rockefeller Foundation Grant through the International Institute of Tropical Agriculture are gratefully acknowledged.

\section{REFERENCES}

Agelopoulos N., Birkett M.A., Hick J.A., Hooper A.M., Pickett J.A., Pow E.M., Smart L.E., Smuiley D.W.M., Wadhams L.J. and Woodcook C.M. (1999) Exploiting semiochemicals in insect control. Pestic. Sci. 55, 225235.

Aldrich J.R. (1999) Predators, pp. 357-381. In Pheromones of Non-lepidopteran Insects Associated with Agricultural Plants (Edited by J. Hardie and A.K. Minks). CAB International, UK.

Alpizar D., Fallas M., Oehlschlager A.C., Gonzalez L.M. and Jayaraman S. (1999) Weevil aggregation pheromones for mass trapping banana weevil in banana and plantain, p. 100. In Abstracts of the XIV
International Plant Protection Congress Jerusalem, Israel, July 1999.

Alvarez P., Escarraman V., Gomez E., Villar A., Jimenez R., Ortiz O., Alcazar J. and Palacois M. (1996) Economic impact of managing sweet potato weevil (Cylas formicarius) with sex pheromones in the Dominican Republic, pp. 83-94. In Case Studies of the Economic Impact of CIP Related Technology (Edited by T. Walker and C. Chrissman). International Potato Centre, Lima, Peru.

Aukema B.H., Dahlsten D.I. and Raffa K.F. (2000) Improved population monitoring of bark beetles and predators by incorporating disparate behavioural responses to semiochemicals. Environ. Entomol. 29, 618-629.

Bakke A. (1981) Utilisation of aggregation pheromones for the control of spruce bark beetle, pp. 210-229. In Insect Pheromone Technology: Chemistry and Applications (Edited by B.A. Leonhardt and M. Beroza). American Chemical Society, Washington.

Bakyalire R. (1992) Aspects of the biology, behaviour and ecology of the banana weevil Cosmopolites sordidus (Germar) (Coleoptera: Curculionidae) in Uganda. MSc Thesis, Makerere University, Kampala, Uganda, 118 pp.

Bartelt R.J. (1999) Weevils, pp. 91-112. In Pheromones of Non-lepidopteran Insects Associated with Agricultural Plants (Edited by J. Hardie and A.K. Minks). CAB International, UK.

Beauhaire J., Ducrot P.H., Malosse C., Rochat D., Ndiege I.O. and Otieno D.O. (1995) Identification and synthesis of sordidin, a male pheromone emitted by Cosmopolites sordidus. Tetrahedron Letters 36, 10431046.

Bell W.J. and Carde R.T. (Eds) (1984) Chemical Ecology of Insects. Chapman and Hall, London. 554 pp.

Bendicho L.A. (1987) Poder de perception de la hormiga Tetramorium guineense para el control biologico del picudo negro del platano. Ciencias de la Agricultura 30, 13-15.

Birch M.C. and Haynes K.F. (1982) Insect Pheromones. Arnold Publishers, London. 247 pp.

Blum M. S. (1974) Pheromone basis of social manifestations in insects, pp. 135-199. In Pheromones (Edited by M.C. Birch). North Holland Publishing Company, Amsterdam.

Bolter C.J., Dicke M., van Loon J.J.A., Visser J.H. and Posthumus M.A. (1997) Attraction of Colorado potato beetle to herbivore-damaged plants during herbivory and after its termination. J. Chem. Ecol. 23, 1003-1023.

Borden J.H. (1977) Behavioural responses of Coleoptera to pheromones, allomones and kairomones, pp. 169-198. In Chemical Control of Insect Behaviour, Theory and Application (Edited by H.H. Shorey and J.J. Mckelvey). John Wiley and Sons, London.

Borden J.H. (1993) Strategies and tactics for the use of 
semiochemicals against forest insect pests in North America, pp. 265-279. In Pest Management Biologically Based Technology (Edited by R.D. Lumsden and J.L. Vaughin). American Chemical Society Conference Proceedings Services, Washington, DC.

Borden J.H., Lindergren B.S. and Chong L. (1980) Ethanol and alpha pinene as synergists for the aggregation pheromones of two Gnathotrichus species. Can. J. For. Res. 10, 290-292.

Bottrell D.G., Barbosa P. and Gould F. (1998) Manipulating natural enemies by plant variety selection and modification: A realistic strategy? Annu. Rev. Entomol. 43, 347-367.

Bowers W.S., Nault 1., Webb R.E. and Dutky S.R. (1972) Aphid alarm pheromone: Isolation, identification and synthesis. Science 177, 121-122.

Braimah H. and Van Emden H.F. (1999) Evidence for the presence of chemicals attractive to the banana weevil, Cosmopolites sordidus (Coleoptera: Curculionidae) in dead banana leaves. Bull. Entomol. Res. 89, 485-491.

Budenberg W.J., Ndiege J.O. and Karago F.W. (1993a) Evidence for volatile male-produced pheromone in banana weevil Cosmopolites sordidus. J. Chem. Ecol. 19, 1905-1916.

Budenberg W.J., Ndiege J.O., Karago F.W. and Hansson B.S. (1993b) Behavioural and electrophysiological responses of the banana weevil, Cosmopolites sordidus to host plant volatiles. J. Chem. Ecol. 19, 267-272.

Burkholder W.E. (1990) Practical use of pheromones and other attractants for stored product insects, pp. 497516. In Behaviour Modifying Chemicals for Insect Management, Applications of Pheromones and Other Attractants (Edited by R.L. Ridgway, R.M. Silverstein and M.N. Inscoe). Marcel Dekker, New York.

Burkholder W.E. and Bousch G.M. (1974) Pheromones in stored product insect trapping and pathogen dissemination. Bull. Org. Eur. Mediter. Prot. Plantes 4, 455-461.

Burkholder W.E. and Ma M. (1985) Pheromones for monitoring and control of stored-product insects. Annu. Rev. Entomol. 40, 559-586.

Butenandt A., Beckmann R., Stamm D. and Hecker E. (1959) Uber densexual-lockstoff des seidenspinners Bombyx mori. Reinderstellung und Konstitution. Naturforsch. B14, 283-284.

Byers J.A. (1992) Attraction of bark beetles, Tomicus piniperda, Hylurgops palliatus and Trypodendron domesticum and other insects to short chain alcohols and monoterpenes. J. Chem. Ecol. 18, 2385-2402.

Byers J.A. (1999) Effects of attraction radius and flight paths on catch of scolytid beetles dispersing outward through rings of pheromone traps. J. Chem. Ecol. 25, 985-1005.

Campion D.G., Critchley B.R. and McVeigh L.J. (1989) Mating disruption, pp. 89-119. In Insect Pheromones in Plant Protection (Edited by A.R. Jutsum and R.F.S. Gordon). John Wiley and Sons, Chichester.

Carde R.T. and Bell W.J. (Eds) (1995) Chemical Ecology of
Insects, Volume 2. Chapman and Hall, New York. 562 pp.

Carde R.T. and Minks A.K. (1995) Control of moths pests by mating disruption: Successes and constraints. Annu. Rev. Entomol. 40, 559-585.

Cerda H., Fernandez G., Lopez A. and Varga J. (1999) Olfactory attraction of the sugar cane weevil (Coleoptera: Curculionidae) to host plant odors, and its aggregation pheromone. Fla. Entomol. 82, 103-112.

Cerda H., Lopez A., Sanoja O., Sanchez P. and Jaffe K. (1996) Atracccion olfactiva de Cosmopolites sordidus Germar (1824) estmulado por volatiles originados en Musaceas de distintas edades y variedades genomicas. Agronomia Trop. 46, 413-429.

Collins P.J., Treverrow N.L. and Lambkin T.M. (1991) Organophosphorus insecticide resistance and its management in the banana weevil borer, Cosmopolites sordidus (Germar) (Coleoptera: Curculionidae), in Australia. Crop Prot. 10, 215-221.

Cork A., De Souza K., Krishnaiah K., Kumar D.V., Ashok Reddy A. and Casagrande E. (1996) Control of the yellow stem borer, Scirpophaga incertulas (Walker) (Lepidoptera: Pyralidae) by mating disruption in rice in India: Effect of unnatural pheromone blends and application time on efficacy. Bull. Entomol. Res. 86, 515-524.

Cork A., Hall D.R., Hodges R.J. and Pickett J.A. (1991) Identification of major component of male produced aggregation pheromone of larger grain borer, Prostephanus trunctus (Horn) (Coleoptera: Cucujidae). J. Stored Prod. Res. 26, 169-174.

Cuille J. (1950) Recherches sur le charancon du bananier (Cosmopolites sordidus Germar). Institut de Fruits et Agrumes Coloniaux series Technicale, (4). 225 pp.

Cuthbert R.A., Peacock J.W. and Cannon W.N. (1977) An estimate of the effectiveness of pheromonebaited traps for the suppression of Scolytus multistiatus. J. Chem. Ecol. 3, 527-537.

David C.T. and Birch M.C. (1986) Pheromone and insect behaviour, pp. 240-267. In Insect Pheromones in Plant Protection (Edited by A.R. Jutsum and R.F.S. Gordon). John Wiley and Sons, New York.

De Groot P. and Debarr G. L. (1998) Factors affecting capture of the white pine cone beetle, Conophthorus coniperda (Schwarz) (Coleoptera: Scolytidae) in pheromone traps. J. Appl. Ent. 122, 281-286.

Delattre P. (1980) Recherche d'une methode d'estimation des populations du charancon du bananier, Cosmopolites sordidus Germar. Oecologia Applicata 1, 83-92.

Dicke M. (1999a) Direct and indirect effects of plants on performance of beneficial organisms, pp. 105-153. In Handbook of Pest Management (Edited by J.R. Ruberson). Marcel Dekker, Inc., New York.

Dicke M. (1999b) Are herbivore-induced plant volatiles reliable indicators of herbivore identity to foraging carnivorous arthropods? Entomol. Exp. Appl. 92, 131142. 
Dicke M. (1999c) Evolution of induced indirect defence of plants, pp. 62-88. In The Ecology and Evolution of Inducible Defenses (Edited by R. Tollrian and C.D. Harvell). Princeton University Press, Princeton NJ.

Dicke M. and Sabelis M.W. (1988) Infochemical terminology: Based on cost-benefit analysis rather than origin of compounds. Funct. Ecol. 2, 131-139.

Dicke M. and Vet L.E.M. (1999) Plant-carnivore interactions: Evolutionary and ecological consequences for plant, herbivore and carnivore, pp. 483-520. In Herbivore: Between Plants and Predators (Edited by H. Olff, V.K. Brown and R.H. Drent). Blackwell and Scientific, Oxford, UK.

Dicke M., Sabelis M.W., Takabayashi J., Bruin J. and Posthumus M.A. (1990) Plant strategies of manipulating predator-prey interactions through allelochemicals: Prospects for application in pest control. J. Chem. Ecol. 16, 3091-3118.

Dicke M., Takabayashi J., Posthumus M.A., Schutte C. and Krips O.E. (1998) Plant-phytoseiid interactions mediated by herbivore induced plant volatiles: Variation in production of cues and in response of predatory mites. Exp. Appl. Acarol. 22, 311-333.

Dickens J.C. (1984) Olfaction in the boll weevil, Anthonomus grandis (Boh.) (Coleoptera: Curculionidae): Electroantennogram studies. J. Chem. Ecol. 10, 1759-1785.

Dickens J.C. (1989) Green leaf volatiles enhance aggregation pheromone of the boll weevil, Anthonomus grandis. Entomol. Exp. Appl. 52, 191-203.

Downham M.C.A., Smit N.E.J.M., Laboke P.O., Hall D.R. and Odongo B. (2001) Reduction of preharvest infestations of African sweet potato weevils Cylas brunneus and C. puncticollis (Coleoptera: Apionidae) using a pheromone mating disruption technique. Crop Prot. 20, 163-166.

Drukker B., Scutareanu P. and Sabelis M.W. (1995) Do anthocorid predators respond to synomones from Psylla-infested pear trees under field conditions? Entomol. Exp. Appl. 77, 193-203.

Eller F.J. and Bartelt R.J. (1996) Grandsoic acid, a male produced aggregation pheromone from the plum curculio, Conotrachelus nenuphar. J. Nat. prod. 59, 451453.

Evenden M.L., Judd G.J.R. and Borden J.H. (2000) Investigation of the mechanisms of pheromone communication disruption of Choristoneura rosaceana (Harris) in a wind tunnel. J. Insect Behav. 13, 499510.

Fletcher T.M., Moore J.C. and Kitching W. (1997) Absolute configuration of sordidin and 7-episordidin emitted by the banana weevil, Cosmopolites sordidus. Tetrahedron Lett. 38, 3475-3476.

Foster S.P. and Harris M.O. (1997) Behavioural manipulation methods for insect pest management. Annu. Rev. Entomol. 42, 123-146.

Giblin-Davis R.M., Gries R., Gries G., Pena-Rojas E., Pinzon I., Pena J.E., Perez A.L., Pierce H.D. and
Oehlschlager A.C. (1997) Aggregation pheromone of palm weevil, Dynamis borassi. J. Chem. Ecol. 23, 22872297.

Giblin-Davis R.M., Oehlschlager A.C., Perez A., Gries G., Gries R., Weissling T.J., Chinchilla C.M., Pena J.E., Hallet R.H., Pierce H.D. and Gonzalez L.M. (1996a) Chemical and behavioural ecology of palm weevils (Curculionidae: Rhynchophorinae). Fla. Entomol. 79, 153-170.

Giblin-Davis R.M., Pena J.E., Oehlschlager A.C. and Perez A.L. (1996b) Optimisation of semiochemicalbased trapping of Metamasius hemipterus sericeus (Coleoptera: Curculionidae). J. Chem. Ecol. 22, 13891410.

Giblin-Davis R.M., Pena E.J. and Duncan R.T. (1994a) Lethal pitfall trap for evaluation of semiochemicalmediated attraction of Metamasius hemipterus sericeus (Olivier) (Coleoptera: Curculionidae). Fla. Entomol. 77, 247-255.

Giblin-Davis R.M., Weissling T.J., Oehlschlager A.C. and Gonzalez L. (1994b) Field responses of Rhynchophorus cruentatus (Coleoptera: Curculionidae) to its aggregation pheromone and fermenting plant volatiles. Fla. Entomol. 77, 196-111.

Gold C.S. (1998) Banana weevil: Ecology, pest status and prospects of integrated control with emphasis on East Africa, pp. 49-74. In Proceedings of the Third International Conference on Tropical Entomology 30 Oct -4 Nov 1994, Nairobi (Edited by R.K. Saini). International Centre of Insect Physiology and Ecology, Nairobi.

Gold C.S., Bagabe M.I. and Sendege R. (1999a) Banana weevil, Cosmopolites sordidus (Germar) (Coleoptera: Curculionidae): Test for suspected resistance to carbofuran and dieldrin in Masaka District, Uganda. African Entomology 7, 189-196.

Gold C.S., Rukazambuga N.D.M., Karamura E.B., Nemeye P. and Night G. (1999b) Recent advances in banana weevil biology, population dynamics and pest status with emphasis on East Africa, pp. 35-50. In Mobilizing IPM for Sustainable Banana Production in East Africa (Edited by E.A. Frison, C.S. Gold, E.B. Karamura and R.A. Sikora). Proceedings of the Workshop on banana IPM held in Nelspruit, South Africa. 23-28 November, 1998. Montpellier, France.

Gold C.S., Ogenga-Latigo M.W., Tushemereirwe W., Kashaija I. and Nankinga C.M. (1993) Farmer perceptions of banana pest constraints in Uganda: Results from a rapid rural appraisal, pp. 3-25. In Biological and Integrated Control of Highland Banana and Plantain: Proceedings of Research Co-ordination Meeting (Edited by C.S. Gold and B. Gemmil). IITA, Ibadan.

Gold C.S., Okech S.H. and Nokoe S. (2001) Evaluation of pseudostem trapping as a control of banana weevil, Cosmopolites sordidus (Germar), populations and damage in Ntugamo district, Uganda. Bull. Entomol. Res. (in press). 
Gries G., Gries R., Perez A.L., Oehlschlager A.C. Gonzales L.M., Pierce H.D., Kouda-Bonafos M., Zebeyou M. and Nanou N. (1993) Aggregation pheromone of African palm weevil, Rhynchophorus phoenicis F. Naturwissenschaften 80, 90-91.

Griffiths D.C., Maniar S.P., Merrit L.A., Mudd A. and Pickett J.A. (1991) Laboratory evaluation of pest management strategies combining antifeedants with insect growth regulator insecticides. Crop Prot. 10, 145-152.

Gross H.R. (1981) Employment of kairomones in the management of parasitoids, pp. 137-150. In Semiochemicals - Their Role in Pest Control (Edited by D.A. Nordlund, R.L. Jones and W.J. Lewis). John Wiley and Sons, New York.

Grostal P. and Dicke M. (1999) Direct and indirect cues of predation risk influence behaviour and reproduction prey: A case for acarine interactions. Behav. Ecol. 10, 422-427.

Hagen K.S., Wall E.F. and Tassan R.L. (1971) The use of food sprays to increase effectiveness of entomophagous insects. Proc. Tall Timbers Conf. Ecol. Anim. Contr. by Habitat Manage. 2, 59-81.

Hall D.R., Chamberlain D.J., Cork A., Desouza J.L., McVeigh L.J., Ahmad Z., Krishnaiah K., Brown N.J., Casagrade E. and Jones O.T. (1994) The use of pheromones for mating disruption of cotton bollworms and rice stem borer in developing countries. Brighton Crop Prot. Conf.: Pests and Diseases pp. 1231-1238. The British Crop Prot. Council, Farnham, Surrey.

Hallett R.H., Gries G., Gries R., Borden J.H., Czyzewska E., Oehlschlager A.C., Pierce H.D., Angerilli N.P.D. and Rauf A. (1993) Aggregation pheromone of two Asian palm weevils, Rhynchophorus ferrugineus and R. vulneratus. Naturwissenschaften 80, 328-331.

Harari A.R. and Landolt P.J. (1997) Orientation of sugar rootstalk borer weevil, Diaprepes abbreviatus, to weevil frass and food odors. J. Chem. Ecol. 23, 857868.

Hardee D.D. (1982) Mass trapping and trap cropping of the boll weevil Anthonomus grandis Boheman, pp. 6571. In Insect Suppression With Controlled Release Pheromone System Vol. 2 (Edited by A. F. Kydonieus and M. Beroza). CRC Press, Boca Raton, FL.

Hardee D.D., Cross W.H., Mitchell E. B., Huddleston P.M., Mitchell H.C., Merkl M.E. and Davich T.B. (1969) Biological factors influencing responses of the female boll weevil to the male sex pheromone in field and large cage tests. J. Econ. Entomol. 62, 161-165.

Hardee D.D., McKibben G.H., Gueldner R.C., Mitchell E.B., Tumlinson J. H. and Cross W.H. (1972) Boll weevils in nature respond to grandlure, a synthetic pheromone. J. Econ. Entomol. 65, 97-100.

Hardee D.D., Mitchell E.B., Huddleston P.M. and Davich T.B. (1966) A laboratory technique for bioassay of plant attractants for the boll weevil. J. Econ. Entomol. $59,240-241$.
Heard T.A. (1995) Oviposition and feeding preferences of a flower-feeding weevil, Coelocephalapion aculeatum, in relation to conspecific damage to its host-plant. Entomol. Exp. Appl. 76, 203-209.

Hebblethwaite M. (1989) Adoption of pheromones in pest control, pp. 303-322. In Insect Pheromones in Plant Protection (Edited by A.R. Jutsum and R.F.S. Gordon). John Wiley and Sons, New York.

Hord H.Y. and Flippin R.S. (1956) Studies of banana borer in the Honduras. J. Econ. Entomol. 49, 296-300.

Howse P., Stevens I. and Jones O. (1998) Insect Pheromones and Their Use in Pest Management. Chapman and Hall, London. 369 pp.

Jaffe K., Sanchez P., Cerda H., Hernandez J.V., Urdaneta N., Guerra G., Martinez R. and Miras B. (1993) Chemical ecology of the palm weevil Rhynchophorus palmarum (L.) (Coleoptera: Curculionidae): Attraction to host plants and to a male-produced aggregation pheromone. J. Chem. Ecol. 19, 1703-1720.

James D.G., Bartlet R.J. and Moore J.C. (1996) Mass trapping of Carpophilus spp. (Coleoptera: Nititulidae) in stone fruit orchards using synthetic aggregation pheromones and a coattractant: Development of a strategy for population suppression. J. Chem. Ecol. 22, 1541-1556.

Jansson R.K., Heath R.R. and Coffelf J.A. (1989) Temporal and spatial patterns of sweet potato weevil (Coleoptera: Curculionidae) counts in pheromonebaited traps in sweet potato fields in southern Florida. Environ. Entomol. 18, 691-697.

Jansson R.K., Mason L.J. and Heath R.R. (1991) Use of sex pheromones for monitoring and managing Cylas formicarius, pp. 97-138. In Sweet Potato Pest Management, A Global Perspective (Edited by R.K. Jansson and K.V. Raman). Westview Press, Oxford.

Jansson R. K., Mason L.J., Heath R.R., Lecrone S.H. and Forey D.E. (1993) Pheromone trap monitoring system for sweetpotato weevil (Coleoptera; Apionidae) in the Southern United States: Effects of lure type, age, and duration in storage. J. Econ. Entomol. 86, 1109-1115.

Jayaraman S., Ndiege I.O., Oehlschelager A.C., Gonzales L.M., Alpizar D., Fallas M., Budenburg W.J. and Ahuya P. (1997) Synthesis, analysis, and field activity of sordidin, a male-produced aggregation pheromone of the banana weevil, Cosmopolites sordidus. J. Chem. Ecol. 23, 1145-1161.

Kaya G.P., Seshu Reddy K.V., Kokwaro E.D. and Munyinyi D.M. (1993) Pathogenicity of Beauveria bassiana, Metarhizium anisopliae and Serratia marcescens to the banana weevil Cosmopolites sordidus. Biocontrol Sci. Technol. 3, 177-187.

Kehat M., Gothilf S., Dunkelblum E. and Greeberg S. (1980) Field evaluation of female sex pheromone components of the cotton bollworm, Heliothis armigera. Entomol. Exp. Appl. 27, 188-193.

Kiggundu A. (2000) Host plant reactions and resistance mechanisms to banana weevil, Cosmopolites sordidus 
(Germar) in Ugandan Musa germplasm. MSc Thesis. Orange Free State University, South Africa, 98 pp.

Klein M.G. and Lacey L.A. (1999) An attractant trap for auto-dissemination of entomopathogenic fungi into populations of the Japanese beetle Popillia japonica (Coleoptera: Scarabaeidae). Biocontr. Sci. Technol. 9, 151-158.

Koppenhoeffer A.M., Seshu Reddy K.V. and Sikora R.A. (1994) Reduction of banana weevil populations with pseudostem traps. Int. J. Pest Manage. 40, 300-304.

Koppenhoeffer A.M., Seshu Reddy K.V., Madel G. and Lubega C. (1992) Predators of the banana weevil Cosmopolites sordidus Germar (Coleoptera: Curculionidae) in Western Kenya. J. Appl. Ent. 114, 530-533.

Lacey L.A., Martins A. and Ribeiro C. (1994) The pathogenicity of Metarhizium anisopliae and Beauveria bassiana for adults of the Japanese beetle, Popillia japonica (Coleoptera: Scarabaeidae). European J. Entomol. 91, 313-319.

Ladd T.L. and Klein M.G. (1982) Trapping Japanese beetles with synthetic female sex pheromone and food type lures, pp. 57-64. In Insect Suppression With Controlled Release Pheromone Systems Vol. 2 (Edited by A.F. Kydonieus and M. Beroza). CRC Press, Florida.

Landolt P.J. (1997) Sex attractant and aggregation pheromones of male phytophagous insects. Am. Entomol. 43, 12-22.

Landolt P.J. and Phillips T.W. (1997) Host plant influences on sex pheromone behaviour of phytophagous insects. Annu. Rev. Entomol. 42, 371391.

Legget J.E. and Cross W.H. (1978) Boll weevils: The relative importance of colour and pheromone in orientation and attraction to traps. Environ. Entomol. 7, 4-6.

Legget J.E., Dickerson W.A. and Lloyd E.P. (1989) Suppressing low-level boll weevil populations with traps: Influence of trap placement, grandlure concentration and population level. Southwest. Entomol. 13, 205-216.

Lewis W.J. and Martin W.R. (1990) Semiochemicals for use with parasitoids: Status and future. J. Chem. Ecol. 16, 3067-3089.

Lewis W.J. and Nordlund D.A. (1985) Behaviourmodifying chemicals to enhance natural enemy effectiveness, pp. 89-101. In Biological Control in Agricultural IPM Systems (Edited by M.A. Hoy and D.C. Herzog) . Academic Press, New York.

Lewis W.J., Nordlund D.A., Gross H.R., Jones R.L. and Jones S.L. (1977) Kairomones and their use for management of entomophagous insects: Moth scales as a stimulus for predation of Heliothis zea (Boddie) eggs by Chrysopa carnea Stephens larvae. J. Chem. Ecol. 3, 483-487.

Lewis W.J., Nordlund D.A., Gueldner R.C., Teal P.E.A. and Tumlinson J.H. (1982) Kairomones and their use for management of entomophagous insects: XIII. Kairomonal activity for Trichogramma spp. of abdominal tips, excretions and synthetic pheromone blend of Heliothis zea (Boddie) moths. J. Chem. Ecol. 8, 1323-1331.

Liu B. and Sengonca C. (1994) Development of 8-armed olfactometers for measuring olfactory responses of insect predators. Anz. Schaedlingsk. Pflanzen. Umweltsch. 67, 30-34.

Lloyd E.P., Mickibben G.H., Knipling E.F., Legget J.E., Witz J.A., Hartstack D.W. and Lockwood D.F. (1981) Mass trapping for detection, suppression and integration with other suppression measures against the boll weevil, pp. 162-185. In Management of Insect Pests with Semiochemicals: Proceedings of an International Colloquium on Management of Insects with Semiochemicals March 23-28, 1980, Gainesville, Florida (Edited by E.R. Mitchell). Plenum Press, New York

Mafra-Neto A. and Habid M. (1996) Evidence that mass trapping suppresses pink bollworm populations in cotton fields. Entomol. Exp. Appl. 81, 315-323.

Mason L.J. and Jansson R.K. (1991) Disruption of sex pheromones communication in Cylas formicarius (Coleoptera: Apionidae) as a potential means of control. Fla. Entomol. 74, 469-472.

McIntyre B.D., Gold C.S., Kashaija I.N., Ssali H., Night G. and Bwamiki D.P. (2002) Biomass, nutrients, soil water and pest incidence in banana-legume intercrops. Biol. Fertil. Soils (in press).

Mclaughlin R.E., Cleveland T.C., Daum R.J. and Bell M.R. (1969) Development of the bait principle for boll weevil control. Field tests with bait containing a feeding stimulant and sporozoans Glugea gasti and Mattesia grandis. J. Invertebr. Pathol. 13, 429-441.

McNeil J.N. (1991) Behavioural ecology of pheromonemediated communication in moths and its importance in the use of pheromone traps. Annu. Rev. Entomol. 36, 407-430.

McVeigh L.J., Campion D.G. and Critchley B.R. (1990) The use of pheromones for the control of cotton bollworms and Spodoptera spp. in Africa and Asia, pp. 407-415. In Behaviour Modifying Chemicals for Insect Management (Edited by R.L. Ridgway, R.M. Silverstein and M.N. Inscoe). Marcel Dekker, New York.

Metcalf R.L. and Metcalf E.R. (1992) Plant Kairomones in Insect Ecology and Control. Chapman and Hall, London. 254 pp.

Miller C.A. and McDougall G.A. (1973) Spruce budworm moth trapping using virgin females. Can. J. Zool. 51, 853-858.

Mitchell G. (1980) Banana entomology in the Windward Islands. Final Report 1974-1978. 216 pp.

Mori K., Nakayama S. and Takikawa H. (1996) Synthesis and absolute configuration of sordidin, the maleproduced aggregation pheromone of the banana weevil, Cosmopolites sordidus. Tetrahedron Lett. 37, 
3741-3744.

Muirhead-Thomson R.C. (1991) Trap Responses by Flying Insects. The Influence of Trap Design on Capture Efficiency. Academic Press, London. 287 pp.

Nankinga M.C. (1994) Potential of indigenous fungal pathogens for the biological control of the banana weevil, Cosmopolites sordidus (Germar). MSc Thesis, Makerere University, Kampala, Uganda, 99 pp.

Nankinga M.C. (1999) Characterisation of entomopathogenic fungi and evaluation of delivery systems of Beauveria bassiana for the biological control of the banana weevil, Cosmopolites sordidus. PhD Thesis, University of Reading, UK.

Nankinga C.M. and Moore D. (2000) Reduction of banana weevil populations using different formulations of the entomopathogenic fungus Beauveria bassiana. Biocontrol Sci. Technol. 10, 645-657.

Nankinga M.C. and Ogenga-Latigo W.M. (1996) Effect of method of application on the effectiveness of Beauveria bassiana against the banana weevil, Cosmopolites sordidus. African J. Plant Prot. 6, 12-21.

Nankinga M.C., Ogenga-Latigo W.M. and Allard G.B. (1996) Pathogenicity of indigenous isolates of $B$. basssiana and Metarhizium anisopliae to the banana weevil Cosmopolites sordidus (Germar). African J. Plant Prot. 6, 1-11.

Ndiege I.O., Jayaraman S., Oehlschlager A.C., Gonzalez L.M., Alpizar D. and Fallas M. (1996) Convenient synthesis and field activity of a male-produced aggregation pheromone for Cosmopolites sordidus. Naturwissenschaften 83, 280-282.

Noldus J.J (1989) Semiochemicals, for foraging behaviour and quality of entomophagous insects for biological control. J. Appl. Ent. 108, 425-452.

Oehlschlager A.C., Chinchilla C.M. Gonzalez L.M., Jiron L.F., Mexzon R. and Morgan B. (1993) Development of a pheromone based trapping system for Rhynchophorus palmarum (Coleoptera: Curculionidae). J. Econ. Entomol. 86, 1381-1392.

Oehlschlager A.C., McDonald R.S., Chinchilla C.M., and Patschke S.N. (1995) Influence of pheromone based mass trapping system on the distribution of Rhynchophorus palmarum (Coleoptera: Curculionidae) in oil palm. Environ. Entomol. 24, 1005-1012.

Oehlschlager C.O., Alpizar D., Fallas M., Gonzalez L.M. and Jayaraman S. (2000) Pheromone-based mass trapping of the banana weevil, Cosmopolites sordidus and the West Indian sugarcane weevil, Metamasius hemipterus in banana and plantain, p. 155. In Abstracts of the XXI International Congress of Entomology, Iguassu Falls, Brazil, 20-26 August, 2000. ICE, Brazil.

Ogenga-Latigo M.W. and Bakyalire R. (1993) Use of pseudostem traps and coefficient of infestation (PCI) for assessing banana infestation and damage by Cosmopolites sordidus Germar. Africa Crop Sci. J. 1, 31-38.

Okech S.H.O., Karamura E.B. and Gold C.S. (1999) Banana IPM in Uganda, pp. 225-236. In Mobilizing
IPM for Sustainable Banana Production in East Africa: Proceedings of the Workshop on Banana IPM Nelspruit, South Africa. 23-28 November, 1998 (Edited by E.A. Frison, C.S. Gold, E.B. Karamura and R.A. Sikora). Montpellier, France.

Ortiz R., Vuylsteke D., Dumpe B. and Ferris R.S.B. (1995) Banana weevil resistance and corm hardness in $M u s a$ germplasm. Euphytica 86, 95-102.

Pell J.K., Macaulay E.D.M. and Wilding N. (1993) A pheromone trap for dispersal of the pathogen Zoophthora radicans Brefeld. (Zygomycetes: Entomophthorales) amongst populations of the diamondback moth, Plutella xylostella L. (Lepidoptera: Yponomeutidae). Biocontr. Sci. Technol. 3, 315-320.

Pena J.E., Giblin-Davis R.R. and Duncan R. (1995) Impact of indigenous Beauveria bassiana (Balsamo) Vuillemin on banana weevil and rotten sugarcane weevil (Coleoptera: Curculionidae) populations in banana in Florida. J. Agric. Entomol. 12, 163-167.

Phillips T.W. (1997) Semiochemicals of stored product insects: Research and applications. J. Stored Prod. Res. 33, 17-30.

Phillips T.W., West J.R., Foltz J.L., Silverstein R.M. and Lanier G.N. (1984) Aggregation pheromone of the deodar weevil, Pissodes nemorensis (Coleoptera: Curculionidae): Isolation and activity of grandisol and grandisal. J. Chem. Ecol. 10, 1417-1423.

Pickett J.A. (1988) Integrating use of beneficial organisms with chemical crop protection. Phil. Trans. Roy. Soc. Lond. 318, 203-211.

Prokopy R.J. (1981) Epideictic pheromones that influence spacing patterns of phytophagous insects, pp. 181213. In Semiochemicals: Their Role in Pest Control (Edited by D.A. Nordlund, R.L. Jones and W.J. Lewis). Wiley, New York.

Prokopy R.J., Cooley S.S. and Phelan P.L. (1995) Bioassay approaches to assessing behavioural responses of plum curculio adults (Coleoptera: Curculionidae) to host odour. J. Chem. Ecol. 21, 1073-1084.

Renwick J.A.A. (1992) New directions in semiochemical research. J. Appl. Entomol. 114, 431-438.

Ridgway R.L., Inscoe M.N. and Dickerson W.A. (1990) Role of the boll weevil pheromone in pest mangement, pp. 437-471. In Behaviour Modifying Chemicals for Insect Management: Applications of Pheromones and Their Attractants (Edited by R.L. Ridgway, R.M. Silverstein and M.N. Inscoe). Marcel Dekker Inc., New York.

Rochat D., Gonzalez V., Mariau D., Villanueva G. and Zaggatti P. (1991) Evidence for a male-produced aggregation pheromone of the American palm weevil, Rhynchophorus palmarum (Coleoptera: Curculionidae). J. Chem. Ecol. 17, 1221-1230.

Rochat D., Meillour P.N., Rafael J.E., Molasse C., Perthuis B., Morin J. and Descoins C. (2000) Identification of pheromone synergists in American palm weevil, Rhynchophorus palmarum and attraction of related 
Dynamis borass. J. Chem. Ecol. 26, 155-187.

Roche R. and Abreu S. (1983) Control del picudo negro del platano (Cosmopolites sordidus) por la hormiga Teteramorium guineense. Ciencias De la agricultura 17, 41-49.

Roitberg D.B. and Isman M.B. (1992) Insect Chemical Ecology: An Evolutionary Approach. Chapman and Hall, New York. 359 pp.

Roy H.E. and Pell J.K. (2000) Interactions between entomopathogenic fungi and other natural enemies: Implications for biological. Biocontr. Sci. Technol. 10, 737-752.

Rukazambuga N.D., Gold C.S. and Gowen S.R. (1998) Yield loss in East African highland banana (Musa spp., AAA-EA group) caused by the banana weevil, Cosmopolites sordidus Germar. Crop Prot. 17, 581-589.

Sabelis M.W. and Dicke M. (1985) Long range dispersal and searching behaviour, pp. 141-160. In Spider Mites, Their Biology, Natural Enemies and Control. World Crop Pests Vol. 1 (Edited by B. M. Helle and M.W. Sabelis). Elsevier, Amsterdam.

Sappington T.W. and Spurgeon D.W. (2000) Variation in boll weevil (Coleoptera: Curculionidae) captures in pheromone traps arising from wind speed moderation by brush lines. Environ. Entomol. 29, 6368.

Schlyter F. (1992) Sampling range, attraction range and effective attraction radius: Estimates of trap efficiency and communication distance in coleopteran pheromone and host attractant systems. J. Appl. Entomol. 114, 439-454.

Schoeman P.S. and Schoeman M.H. (1999) Transmission of Beauveria bassiana from infected adults of the banana weevil Cosmopolites sordidus (Coleoptera: Curculionidae). African Plant Prot. 5, 53-54.

Schoonhoven L.M. (1990) Host-marking pheromones in Lepidoptera, with sepecial reference to two Pieris spp. J. Chem. Ecol. 16, 3043-3052.

Schwalbe C.P., Burkholder W.E. and Boush G.M. (1974) Mattesia trogodermae infection rates as influenced by mode of transmission, dosage and host species. J. Stored Prod. Res. 10, 161-166.

Sengooba T. (1986) Survey of banana pest problem complex in Rakai and Masaka districts, August 1986: Preliminary trip report. Ministry of Agriculture, Namulonge Research Station, Uganda. Unpublished, 10 pp.

Seshu Reddy K.V., Koppenhoefer A.M. and Uronu B. (1993) Cultural practices for the banana weevil control, pp. 140-146. In Biological and Integrated Control of Highland Banana and Plantain Pests and Diseases. Proceedings of a Research Co-ordination Meeting Cotonou, 12-14 November, 1991 (Edited by C.S. Gold and B. Gemmill). IITA, Ibadan.

Shapas T.J., Burkholder W.E. and Boush G.M. (1977) Population suppression of Trogoderma glabrum by using pheromone luring for protozoan pathogen dissemination. J. Econ. Entomol. 70, 469-474.
Shonouda M.L., Bombosch S., Shalaby A.M. and Osman S.I. (1998) Biological and chemical characterization of kairomone excreted by the bean aphids, Aphis fabae Scop. (Homoptera: Aphididae) and its effects on predator Metasyrphus corollae Fabr. I. Isolation, identification and bioassay of aphid-kairomone. J. Appl. Ent. 122, 15-23.

Sikora R.A., Bafokuzara N.D., Mbwana A.S.S., Oloo G.W., Uronu B. and Seshu Reddy K.V. (1989) Interrelationship between banana weevil, root lesion nematode and agronomic practices and their importance for banana decline in the united Republic of Tanzania. FAO Plant Prot. Bull. 37, 151-157.

Silverstein R.M. (1981) Pheromones: Background and potential for use in insect control. Science 213, 13261332.

Smit N.E.M., Downham M.C.A., Odongo B., Hall D.R. and Laboke P.O. (1997) Development of pheromone traps for control and monitoring of sweet potato weevils, Cylas puncticollis and C. brunneus, in Uganda. Entomol. Exp. Appl. 85, 95-104.

Srivastava C.P., Pimbert M.P. and Reed W. (1992) Monitoring of Helicoverpa (Heliothis) armigera (Hubner) moths with light and its pheromone trap in India. Insect Sci. Applic. 13, 205-210.

Stapel J.O., Cortesero A.M., Demoraes C.M., Tumlinson J.H. and Lewis W.J. (1997) Effects of extrafloral nectar, honeydew and sucrose on searching behaviour and efficiency of Microplitis croeipes (Hymenoptera: Braconidae) in cotton. Environ. Entomol. 26, 617-623.

Staten R.T., El-Lissy O. and Antilla L. (1997) Successful area-wide program to control the bollworm by mating disruption, pp. 383-396. In Insect Pheromones: New Research Directions (Edited by R.T. Carde and A.K. Minks). Chapman and Hall, New York.

Steidle J.L.M. and Van Loon J.J.A. (2002) Chemoecology of parasitoids and predator oviposition behaviour. In Chemoecology of Insect Eggs and Egg Deposition (Edited by M. Hilker and T. Meiners). Blackwell, London (in press).

Stover R.H. and Simmonds N.W. (1987) Bananas, p. 467. Tropical Agricultural Series, Scientific and Technical, UK.

Suckling D.M. (2000) Issues affecting the use of pheromones and other semiochemicals in orchards. Crop Prot. 19, 677-683.

Tadas P.L., Sarnaik D.N., Kene H.K. and Satpute U.S. (1994) Effect of weather parameters on monitoring of cotton bollworms with pheromones. Punjabrao Krishi Vidyapeeth Res. J. 18, 87-90.

Tamhankar A.J., Gahukar R.T. and Rajendran T.P. (2000) Pheromones in the management of major lepidopterous and coleopterous pests of cotton. Integr. Pest Manage. Rev. 5, 11-23.

Tinzaara W., Karamura E.B. and Tushemereirwe W. (1999) Preliminary observations on natural enemies associated with the banana weevil Cosmopolites sordidus Germar in Uganda. INFOMUSA 8, 28-29. 
Tinzaara W., Tushemereirwe W. and Kashaija I. (2000) Efficiency of pheromones and trap types in the capture of the banana weevil Cosmopolites sordidus Germar in Uganda. Uganda J. Agric. Sci. 5, 91-95.

Trematerra P. (1997) Integrated pest management of stored-product insects: Practical utilization of pheromones. Anz. Schadlinegsk. Pflanz. Umwelts. 70, 41-44.

Tumlinson J.H., Hardee D.D., Gueldner R.C., Thompson A.C., Hedin P.A. and Minyard J.P. (1969) Sex pheromone produced by male boll weevil: Isolation, identification and synthesis. Science 166, 1010-1012.

Tumlinson J.H., Klein M.G., Doolittle R.E., Ladd T.L. and Proveaux A.T. (1977) Identification of the female Japanese beetle sex pheromone: Inhibition of male response by an enantiomer. Science 197, 789-792.

Turlings T.C.J., Loughrin J.H., McCall P.J., Rose U.S.R., Lewis W.J. and Tumlinson J.H. (1995) How caterpillar-damaged plants protect themselves by attracting parasitic wasps. Proc. Nat. Acad. Sci. USA 92, 4169-4174.

Turlings T.C.J., Scheepmaker J.W.A., Vet L.E.M., Tumlinson J.H. and Lewis W.J. (1990) How contact foraging experiences affect preferences for hostrelated odors in the larval parasitoid Cotesia marginiventris (Cresson) (Hymenoptera: Braconidae). J. Chem. Ecol. 16, 1577-1589.

Van Loon J.J.A., De Vos E.W. and Dicke M. (2000) Orientation behaviour of the predatory hemipteran Perillus bioculatus to plant and prey odours. Entomol. Exp. Appl. 96, 51-58.

Vega F.E., Dowd F.P. and Bartelt R. (1995) Dissemination of microbial agents using an auto-inoculating device and several insect species as vectors. Biol. Contr. 5, 545-552.

Vega F.E., Dowd P.F., Lacey L.A., Pell J.K., Jackson D.M. and Klein M.G. (2000) Dissemination of beneficial microbial agents by insects, pp. 153-177. In Field Manual of Techniques in Invertebrate Pathology. Application and Evaluation of Pathogens for Control of
Insects and other Invertebrate Pests (Edited by A.L. Lacey and H.K. Kaya). Kluwer Academic Publishers, Dordrecht.

Vet L.E.M. and Dicke M. (1992) Ecology of infochemical use by natural enemies in a tritophic context. Annu. Rev. Entomol. 32, 141-172.

Visser J.H. (1986) Host odour perception in phytophagous insects. Annu. Rev. Entomol. 31, 121-144.

Vite J.P. and Baader E. (1990) Present and future use of semiochemicals in pest management of bark beetles. J. Chem. Ecol. 16, 3031-3041.

Walgenbach C.A., Burkholder W.E., Curtis M.J. and Khan Z.A. (1987) Laboratory trapping studies with Sitophilus zeamais (Coleoptera: Curculionidae). J. Econ. Entomol. 80, 763-767.

Walgenbach C.A., Phillips J.K., Faustini D.L. and Burkholder W.E. (1983) Male-produced aggregation pheromone of the maize weevil, Sitophilus zeamais, and interspecific attaction between three Sitophilus zeamais species. J. Chem. Ecol. 9, 931-841.

Wall C. (1989) Monitoring and spraying time, pp. 3966. In Insect Pheromones in Plant Protection (Edited by A.R. Jutsum and R.F.S. Gordon). John Wiley and Sons, Chichester.

Weissling T.J., Giblin-Davis R.M. and Scheffrahn R.H. (1993) Laboratory and field evidence of male produced aggregation pheromone in Rhynchophorus cruentatus (F.) (Coleoptera: Curculionidae). J. Chem. Ecol. 19, 1195-1203.

Weslein J. (1992) Effects of mass trapping on Ips typographus (L.) populations. J. Appl. Entomol. 114, 228-232.

Whittaker R.H. and Feeny P.P. (1971) Allelochemicals; chemical interactions between species. Science 171, 757-770.

Zimmermann G. (1992) Use of the fungus, Beauveria brongniartii, for the control of European cockchafers, Melolontha spp. in Europe, pp. 199-208. In Use of Pathogens in Scarab Pest Management (Edited by T.A. Jackson and T.R. Glare). Intercept, Andover. 
